DEPARTMENT OF THE INTERIOR

U.S. GEOLOGICAL SURVEY

\title{
The strategic and critical mineral resources \\ of the southern part of the \\ National Petroleum Reserve in Alaska
}

by

Inyo Ellersieck and I. L. Tailleur

Open-File Report 86-158

This report is preliminary and has not been edited or reviewed for conformity with Geological Survey standards and nomenclature. 
Summary .................... 1

Introduction ................. 1

Previous Work .................. 1

Mineral Deposit Models ................ 2

Assessment of Potential for Individual Minerals . . . . . 3

Selected Elements with Potential in Southern NPRA

Zinc, Lead, Silver, Cadmium, Antimony ........ 4

Chromium ................ 5

Copper, Cobalt ............... 5

Fluorspar................ 5

Manganese ................. 6

Platinum-Group Elements .......... . . 6

Vanadium ................ 6

References ............... 7

\section{ILLUSTRATIONS}

Figure 1. Map of southern part of NPRA showing Drinkwater Creek and Story Creek mineral occurrences . . . . 4

\section{TABLES}

Table 1. Strategic and Critical Minerals and Elements . . 10

2. Ore deposit types associated with strategic and critical minerals 
THE STRATEGIC AND CRITICAL MINERAL RESOURCES

OF THE SOUTHERN PART OF THE

NATIONAL PETROLEUM RESERVE IN ALASKA

By Inyo Ellersieck and I. L. Tailleur

\section{SUMMARY}

The southern part of the National Petroleum Reserve in Alaska (NPRA) has not been explored in detail for strategic and critical minerals and elements. The geology, however, is fairly well known. By analogy with other, well-explored regions of similar geology, there is a very low potential for recoverable resources of most strategic and critical elements within the southern part of NPRA. The only strategic and critical elements known to exist in potentially recoverable quantities are zinc, lead, silver, cadmium, and antimony. Recoverable resources of some other elements may exist in currently undiscovered mineral deposits.

\section{INTRODUCTION}

Strategic and critical minerals are defined by the Strategic and Critical Minerals Stockpiling Act of 1979 (Public Law 96-41) as "...those that are needed to supply the military, industrial and civilian needs of the United States during a national emergency and whose supplies are dependent on imports." (Congressional Budget Office, 1983). The National Defense Stockpile includes 93 commodities derived from 34 different elements or minerals. Thirty-one of these elements and minerals are listed in Table 1. Jewel bearings and molybdenum have been excluded; jewel bearings because they are a synthetic product, and molybdenum because it is a net export of the $U$. $S$.

The arctic climate and remote location of southern NPRA influence the feasibility of extracting mineral resources. The distance from industrial areas presently makes transportation costs prohibitive for those materials which are required in large quantities at low unit cost, such as silica sand. There is no infrastructure of roads, rails, port facilities, or electric power at the present time. Mineral deposits that might be economically recoverable in populated areas that have such an infrastructure might be sub-economic within NPRA. Development of one resource which is sufficiently valuable to justify the capital investment necessary to build transportation and power facilities, however, could favorably affect the viability of smaller or less valuable mineral resources. Petroleum and coal, which have some potential for development within southern NPRA, therefore could have an impact on the future development of strategic and critical mineral resources of this area. This report is concerned only with the geological potential for occurrences of strategic and critical minerals in southern NPRA; considering whether such occurrences, if discovered, could be brought into production is beyond the scope of this report.

\section{PREVIOUS WORK}

Regional geologic mapping of southern NPRA is relatively complete (Tailleur and others, 1966; Mayfield and others, 1978; Curtis and others, 1982: Ellersieck and others, 1982; Mayfield and others, 1982; Sable and others, 1984a, 1984b, 1984c). Stream-sediment geochemical sampling has been done on a reconnaissance scale within the Reserve (Theobald and Barton, 1978) and in adjoining regions (Curtis and others, 1980; Ellersieck and others, 
1980). Some studies have been made of non-fuel mineral resources in NPRA and the adjoining regions (Churkin and others, 1978; Jansons and Baggs, 1980; Jansins and Parke, 1981; Nokleberg and Winkler, 1982; Ellersieck and others, 1982). Reports on some ore deposits and mineral occurrences outside of NPRA provide information about the potential for undiscovered mineral resources in geologically similar areas within the Reserve (Tailleur, 1970; Degenhart and others, 1978; Mayfield and others, 1979; Jones, 1982; Hitzman, 1983).

\section{MINERAL DEPOSIT MODELS}

Although most of the strategic and critical elements can be found in trace amounts in most places in the earth's crust, they are present in concentrations that are economically recoverable only within certain geologic environments. Some are currently recovered from several different geologic settings, while others are more restricted in their occurrence. Knowledge of the geologic settings that have historically produced minerals or groups of minerals has been incorporated into models of ore deposit types (Cox, 1983a, 1983b). Each ore deposit model takes into account the tectonic setting, associated rock types, and mineralogy of the ore. These models can be used to predict whether or not the geological setting of southern NPRA is favorable for an undiscovered ore deposit type. The models can also be used to predict the occurrence of minerals that have not yet been identified within known deposits in NPRA.

An assessment of resources in undiscovered deposits is necessarily qualitative and based on subjective judgments. Although NPRA has not been explored in detail for strategic and critical minerals specifically, the current state of geologic knowledge is sufficient to eliminate the possibility of some ore deposit types with a high degree of confidence. Other deposit types may be permissible in the geologic framework as it is known at this time, but there is no known indication that they are present. Some mineral occurrences have been discovered in NPRA, providing evidence that undiscovered occurrences of a similar nature are possible.

The main criterion we used to assess the possibility of deposit types is the presence or absence of suitable host rock types. Even though large areas of the Reserve are concealed beneath surficial deposits, they are unlikely to contain rock types that are unknown in the exposed areas which have been mapped. It is highly unlikely, for example, that granitic rocks of any great extent are present in the southern part of the Reserve. Therefore ore deposits associated with granitic rocks are not expected.

A second, more subjective criterion is tectonic setting and geologic history. Certain ore deposit types are thought to be associated with specific geologic events. The model of tectonic development used in this assessment is based on the synthesis of events described by Mayfield and others, 1983. As ore deposits are studied in other parts of the world, new interpretations about their geologic setting and mineralogy are sure to evolve. The assessment of the potential for strategic and critical minerals in NPRA will probably be revised in the future, as new information about the geology of NPRA is gained, and as new ideas about ore deposits are developed.

Table 2 shows a greatly simplified list of deposit types and the strategic and critical minerals or elements commonly found within them. These 
deposit types have been grouped into four categories. Category one includes mineral $0:$ currences identified in NPRA which have a high potential for development. Category two includes deposit types which have been identified within the Reserve or in adjoining regions, but which seem to have a low probability of sufficient grade or quantity to make recovery feasible, either in the identified occurrences or in possible undiscovered ones. Category three includes deposit types which have not been identified within NPRA or the adjoining regions, but which are permissible within the geologic framework of NPRA as it is known today. If a particular deposit model calls for a special geologic condition, and we do not know whether or not the condition exists, we made the assumption that the deposit type is possible until proven

otherwise. Category four includes ore deposit types which are constrained to rock types and geologic environments which are highly unlikely within southern NPRA.

\section{ASSESSMENT OF POTENTIAL FOR INDIVIDUAL MINERALS}

Table 1 summarizes the potential for individual strategic and critical minerals, based on our estimates of the probability for the deposit types in table 2. In addition to the uncertainty about the presence or absence of undiscovered ore deposit types, there also may be an uncertainty about the minor elements a given ore deposit type may contain. For example, bismuth is a common byproduct of lead ore, but some lead-bearing ores do not contain recoverable quantities of bismuth (Hasler and others, 1972).

The potential for each element or mineral in table one has been listed two categories. An element or mineral is classified as "identified" if it has been seen in a mineral occurrence in or near the Reserve, or if it is detected in chemical analyses from these occurrences. If an element or mineral is classified as "not identified", its potential is based on analogy with ore deposit types which have not been discovered in the Reserve. Elements identified in the Reserve may also occur in other, undiscovered, deposit types, so they are assigned a potential in both categories.

The estimation of potential is divided into three levels. "High" potential means that the element is known to occur in recoverable concentrations within southern NPRA, and there is a good chance that it may be present in quantities that would make recovery economically feasible. The only strategic and critical minerals in this category are lead, zinc, silver, cadmium, and antimony. Elements and minerals with "low" potential are dependent upon either the discovery of ore deposit types not presently known within the Reserve, or upon the discovery of recoverable quantities within known deposit types. Minerals and elements classified as having "low" potential actually possess the greatest level of uncertainty about the potential resource. If present in the Reserve, they may be present in quantities as high or higher than elements classified as having "high" potential. Elements and minerals with "very low" potential are those not found in any deposit types that have a significant probability of being found in southern NPRA. 


\section{SELECTED ELEMENTS WITH POTENTIAL IN SOUTHERN NPRA}

\section{ZINC, LEAD, SILVER, CADMIUM, ANTIMONY}

Zinc-lead-silver occurrences have been discovered within the Reserve at Drenchwater Creek and Story Creek (fig. 1). Both of these occurrences are within the Brooks Range allochthon, a tectonic unit that also contains several other zinc-lead-silver occurrences (Mayfield and others, 1979). The Lik deposit (Wall Street Journal, 1977) and the Red Dog deposit (Jones, 1982) southwest of NPRA have been drilled and shown to contain significant reserves. Although the Drenchwater Creek occurrence has been classified as a volcanogenic sulfide deposit (Nokleberg and Winkler, 1982), other zinc-leadsilver occurrences in the Brooks Range allochthon do not seem to be closely associated with igneous rocks. It is possible that the Drenchwater Creek occurrence is a special case of a broader class of mineral deposits within the Brooks Range allochthon. Whatever mineral deposit models are used, the Brooks Range allochthon within NPRA has a high potential for the discovery of additional zinc-lead-silver occurrences.

Both the Drenchwater Creek and Story Creek occurrences have outcrops of ore-grade material, but the extent of this material cannot be determined from surface exposures. Drilling and geophysical surveys are needed to measure the resources in place at these two occurrences. Geochemical sampling is needed to determine the minor elements within the ore. The limited analyses available (Churkin and others, 1978; Jansons and Baggs, 1980; Jansons and Parke, 1981) suggest that antimony and cadmium are potential byproducts, but bismuth may not be present in recoverable quantities.

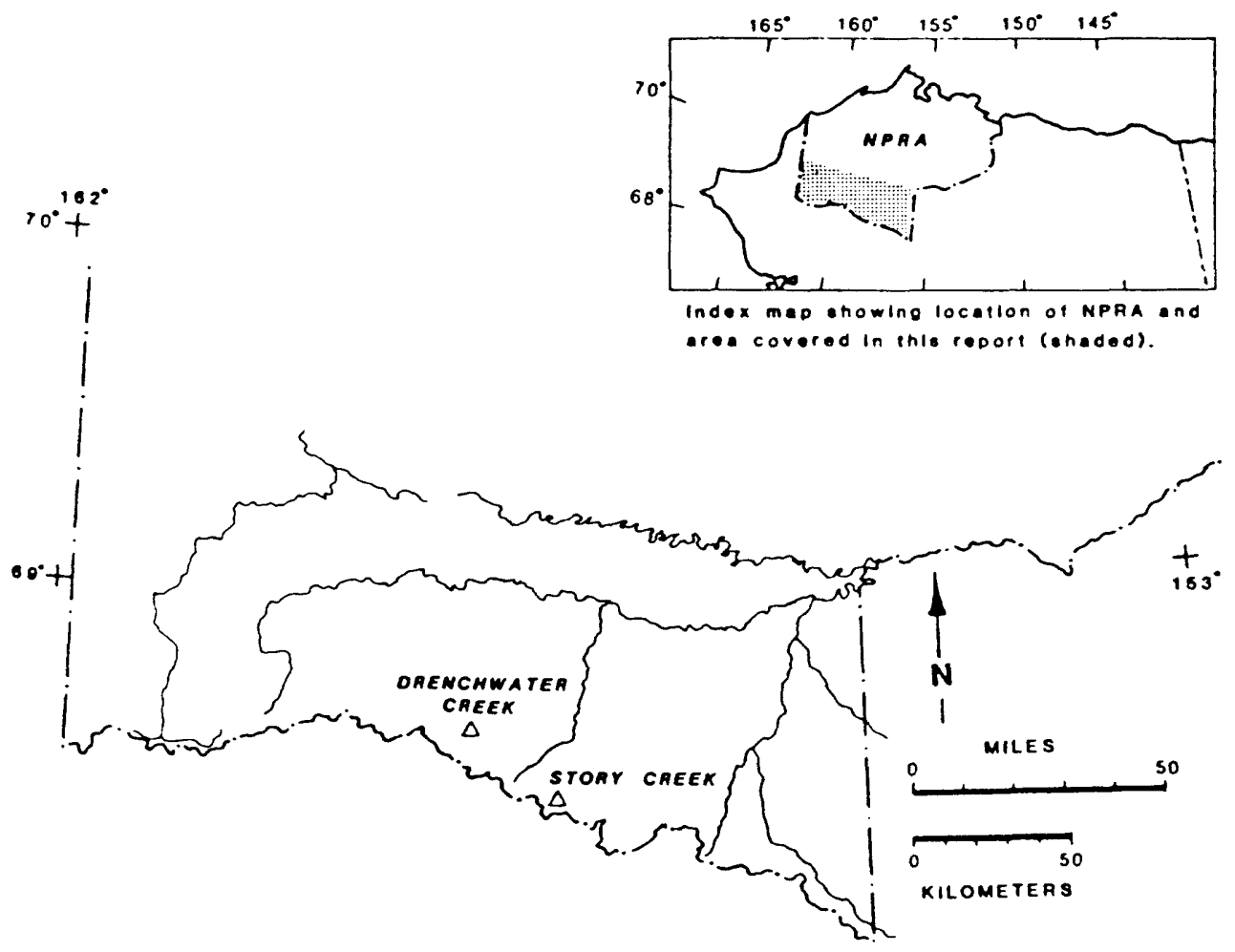

Figure 1 -Southern part of the National Petroleum Reserve in Alaska (NPRA) showing Drenchwater Creek and Story Creek mineral occurrences. 
CHROMIUM

Chromium is present in the form of chromite layers in ultramafic bodies of the Misheguk Mountain allochthon (Mayfield and others, 1983). These layers are too thin and discontinuous to be minable at any of the locations where they have been seen (Degenhart and others, 1978; Jansons and Baggs, 1980). There are chromium stream-sediment geochemical anomalies in the Reserve (Theobald and Barton, 1978), which have their source in an ultramafic body that is just outside the boundary of the Reserve. Outcrops of ultramafic igneous rocks belonging to the Misheguk Mountain allochthon probably do not occur within the Reserve (Mayfield and others, 1983). Chromium, although present, is probably not a feasibly recoverable resource.

COPPER, COBALT

Copper sulfide minerals are present in trace amounts in the Drenchwater Creek and Story Creek zinc-lead-silver occurrences. Analyses of lead and zinc sulfides from these occurrences show anomalously high amounts of copper relative to the country rocks, but not recoverable concentrations. Cobalt is present in trace amounts in analyses of sulfide minerals in the same occurrences, but it is probably not enriched enough to be recoverable as a byproduct.

Copper and cobalt-bearing sulfides are present in the Ruby Creek deposit on the south side of the Brooks Range (Hitzman, 1983). The host rocks for the Ruby Creek deposit are carbonates of Devonian age. The Ivotuk and Kelly sequences in NPRA contain carbonates of Mississippian age (Mayfield and others, 1983) which are potential exploration targets for the same kind of deposit as Ruby Creek. Stream-sediment geochemistry in the vicinity of the outcrops of these sequences does not reveal anomalous concentrations of copper or cobalt. Reconnaissance geologic mapping has not turned up any positive indications of copper or other sulfide deposition in the carbonate parts of these sequences.

Basaltic volcanic rocks on Memorial Creek (Mayfield and others, 1978) have a small chance of containing copper sulfide deposits. This area has not been explored in detail.

\section{FLUORSPAR}

Fluorite (fluorspar) has been noted in thin sections of samples from Drenchwater Creek (Nokleberg and Winkler, 1982). The amounts are very small, and the possibility of finding recoverable quantities in this deposit is fairly low.

There is an occurrence of fluorite veins in dolomite belonging to the Ivotuk sequence at Mount Bupto (Jansons and Baggs, 1980). The primary source of this fluorite is unknown, but the amount visible at the surface is very small. There is some potential for fluorite in association with undiscovered lead-zinc or copper-cobalt deposits within the Ivotuk or Kelly sequences. 


\section{MANGANESE}

The pebble shale member of the Early Cretaceous Kongakut Formation in the northeastern Brooks Range contains an interval approximately 50 meters thick that has manganiferous beds. The manganese is in the form of sedimentary manganese carbonate, and some analyses show up to five percent manganese (Detterman and others, 1975). Within NPRA, a thin interval of clay shale near the base of the Cretaceous section in the Ivotuk sequence may be correlative with the pebble shale, but manganiferous beds have not been recognized.

Sedimentary manganese is also geologically possible at the top of the Carboniferous section in the Ivotuk sequence. There are also very small manganiferous concretions in the Etivluk Group cherts in several sequences. Stream-sediment geochemical sampling has not indicated any unusual concentrations of manganese in NPRA, however. The potential for manganese is unknown.

\section{PLATINUM-GROUP ELEMENTS}

Some prospecting has been done for platinum-group elements in placer deposits derived from the mafic-ultramafic bodies of the Misheguk Mountain allochthon. Prospect pits in the Avan Hills body revealed sub-economic amounts of platinum (C. F. Herbert, British Petroleum Co., written communication, 1977). Some geochemical samples of the Avan Hills and the Misheguk Mountain bodies revealed no anomalous concentrations of platinumgroup elements (Degenhart and others, 1978). The chances of there being recoverable concentrations of platinum-group elements in placers within NPRA, where the mafic-ultramafic bodies do not outcrop, is very low.

\section{VANADIUM}

There is an unknown potential for vanadium in sedimentary deposits in the Nanushuk Group in the northern part of southern NPRA. Vanadium is commonly a co-product with uranium in this type of deposit, but the source areas for the sands of the Nanushuk Group make it unlikely that uranium will be found in this region. Therefore this type of deposit, if present, would need to be mined for vanadium alone and might not be economically viable.

Some vanadium is produced as a by-product from the distillation of crude oil. Therefore there is an unknown potential for vanadium in undiscovered oil resources in southern NPRA. 


\section{REFERENCES}

Churkin, Michael, J., Mayfield, C. F., Theobald, P. K., Barton, H. N., Nokleberg, W. J., Winkler, G. R., and Huie, Carl, 1978, Geological and geochemical appraisal of metallic mineral resources, southern National Petroleum Reserve in Alaska: U.S. Geological Survey Open-File Report 78$70 \mathrm{~A}, 82 \mathrm{p}$.

Congressional Budget Office, 1983, Strategic and critical nonfuel minerals: problems and policy alternatives: Washington, D. C., 85 p.

Cox, Dennis P., editor, 1983a, U.S. Geological Survey-Ingeominas mineral resource assessment of Colombia: ore deposit models: U.S. Geological Survey Open-File Report 83-423, 49 p.

Cox, Dennis P., editor, 1983b, U. S. Geological Survey-Ingeominas mineral resource assessment of Colombia: additional ore deposit models: U.S. Geological Survey Open-File Report 83-901, 31 p.

Curtis, S. M., Ellersieck, Inyo, Mayfield, C. F., and Tailleur, I. L., 1980, Map showing silver, copper, lead, and zinc stream-sediment anomalies in Misheguk Mountain quadrangle, Alaska: U.S. Geological Survey Open-File Report 80-315, scale 1:250,000.

Curtis, S. M., Ellersieck, Inyo, Mayfield, C. F., and Tailleur, I. L., 1982, Reconnaissance geologic map of the southwestern Misheguk Mountain quadrangle, Alaska: U.S. Geological Survey Open-File Report 82-611, scale $1: 63,360,2$ sheets, $42 \mathrm{p}$.

Degenhart, C. E., Griffis, R. J., McOuat, J. F., and Bigelow, C. G., 1978, Mineral studies of the western Brooks Range performed under contract to the U.S. Bureau of Mines, contract \#J0155089: U.S. Bureau of Mines Open-File Report 103-78, 529 p.

Detterman, R. L., Reiser, H. N., Brosgé, W. P., and Dutro, J. T., Jr., 1975, Post-Carboniferous Stratigraphy, Northeastern Alaska: U.S. Geological Survey Professional Paper 886, $46 \mathrm{p}$.

Ellersieck, Inyo, Curtis, S. M., Gruzensky, A. L., Mayfield, C. F., and Tailleur, I. L., 1980, Copper, lead and zinc in stream-sediment samples from the DeLong Mountains quadrangle, Alaska: U.S. Geological Survey Open-File Report 80-795, scale 1:63,360, 3 sheets.

Ellersieck, Inyo, Curtis, S. M., Mayfield, C. F., and Tailleur, I. L., 1982, Reconnaissance geologic map of the south-central Misheguk Mountain quadrangle, Alaska: U.S. Geological Survey Open-File Report 82-612, scale $1: 63,360,2$ sheets, 37 pages.

Ellersieck, Inyo, Jansons, Uldis, Mayfield, C. F., and Tailleur, I. L., 1982, The Story Creek and Whoopee Creek lead-zinc-silver occurences, western Brooks Range, Alaska, in Coonrad, Warren L., ed., United States Geological Survey in A7aska: Accomplishments during 1980: U.S. Geological Survey Circular 844, p. 35-38. 
Hasler, J. W., Miller, M. H., and Chapman, R. M., 1972, Bismuth, in Brobst, Donald $A_{\text {., }}$ and Pratt, Walden P., eds., United States Mineral Resources: U.S. Geological Survey Professional Paper 820, p. 95-98.

Hitzman, M. W., 1983, Geology of the Cosmos Hills and its relationship to the Ruby Creek copper-cobalt deposit: Stanford University Ph.D. dissertation, 266 p.

Jansons, Uldis, and Baggs, Donald W., 1980, Mineral investigations of the Misheguk Mountain and Howard Pass quadrangles, National Petroleum Reserve, Alaska: U.S. Bureau of Mines Open-file Report 38-80, 76 p.

Jansons, Uldis, and Parke, Mary Ann, 1981, 1978 mineral investigations in the Misheguk Mountain and Howard Pass quadrangles, Alaska: U.S. Bureau of Mines Open-File Report 26-81, 195 p.

Jones, Allan, 1982, Red Dog ore deposit said spectacular: Northern Miner, $v$. 67 , no. 51, p. 1 .

Mayfield, C. F., Tailleur, I. L., Mull, C. G., and Sable, E. G., 1978, Bedrock geologic map of the south half of the National Petroleum Reserve in

Alaska: U.S. Geological Survey Open-File Report 78-70B, scale 1:500,000, 2 sheets.

Mayfield, C. F., Curtis, S. M., Ellersieck, I. F., and Tailleur, I. L., 1979, Reconnaissance geology of the Ginny Creek zinc-lead-silver and Nimiuktuk barite deposits, northwestern Brooks Range, Alaska: U.S. Geological Survey Open-File Report 79-1092, scale 1:63,360, 2 sheets, 20 p.

Mayfield, C. F., Curtis, S. M., Ellersieck, Inyo, Mayfield, C. F., and Tailleur, I. L., 1982, Reconnaissance geologic map of the southeastern Misheguk Mounta in quadrangle, Alaska: U.S. Geological Survey Open-File Report 82-613, scale $1: 63,360,2$ sheets, $39 \mathrm{p}$.

Mayfield, C. F., Tailleur, I. L., and Ellersieck, Inyo, 1983, Stratigraphy, structure, and palinspastic synthesis of the western Brooks Range, northwestern Alaska: U.S. Geological Survey Open-File Report 83-779, 5 sheets, $61 \mathrm{p}$.

Nokleberg, Warren J., and Winkler, Gary R., 1982, Stratiform zinc-lead deposits in the Drenchwater Creek area, Howard Pass quadrangle, northwestern Brooks Range, Alaska: U. S. Geological Survey Professional Paper 1209, scale $1: 19,800,2$ sheets, 22 p.

Sable, E. G., Chapman, R. M., and Tailleur, I. L., 1984, Geologic map of the west-central Kukpowruk-Nuka Rivers region, northwestern Alaska: U.S. Geological Survey Miscellaneous Field Investigations Map MF-1669, scale $1: 63,360,2$ sheets.

Sable, E. G., Dutro, J. J. Jr., Morris, R. H., and Tailleur, I. L., 1984, Geollogic map of the eastern Kukpowruk-Nuka Rivers region, northwestern Alaska: U.S. Geological Survey Miscellaneous Field Investigations Map MF-1671, scale $1: 63,360,2$ sheets. 
Sable, E. G., Mangus, M. D., Morris, R. H., and Dutro, J. J., Jr., 1984, Geologic map of the east-central Kukpowruk-Nuka Rivers region, northwestern Alaska: U.S. Geological Survey Miscellaneous Field Investigations Map MF -1670, scale $1: 63,360,2$ sheets.

Tailleur, I. L., 1970, Lead-, zinc-, and barite-bearing samples from the western Brooks Range, Alaska, with a section on petrography and mineralogy by G. D. Eberlein and Ray Wear: U.S. Geological Survey OpenFile Report $445,16 \mathrm{p}$.

Tailleur, I. L., Kent, B. H., and Reiser, H. N., 1966, Outcrop/geologic maps of the Nuka-Etivluk region, northern Alaska: U.S. Geological Survey Open-File Report 266, scale $1: 63,360,7$ sheets.

Theobald, P. K., and Barton, H. N., 1978, Basic data for the geochemical evaluation of National Petroleum Reserve, Alaska: U.S. Geological Survey Open-File Report 78-700. scale 1:250,000, 2 sheets, 102 p.

Wall Street Journal, 1977, Houston 0 il, partner have significant finds of minerals in Alaska: September 13, 1977, (final $\star \star \star$ eastern edition), $p$. 16.

9 


\begin{tabular}{|c|c|c|c|}
\hline Aluminum & -- & very low & \\
\hline Ant imony & high & low & byproduct of lead and zinc \\
\hline Asbestos & -- & very low & \\
\hline Beryllium & -- & very low & \\
\hline Bismuth & low & low & possible byproduct of lead \\
\hline Cadmium & high & low & byproduct of zinc \\
\hline Chromium & low & very low & $\begin{array}{l}\text { present in sub-economic } \\
\text { concentrations }\end{array}$ \\
\hline Cobalt & very low & low & $\begin{array}{l}\text { present in trace amounts } \\
\text { in lead-zinc occurrences }\end{array}$ \\
\hline Columbium & -- & very low & \\
\hline Copper & low & low & \\
\hline Diamond & -- & very low & \\
\hline Fluorspar & low & low & $\begin{array}{l}\text { present in sub-economic } \\
\text { concentrations }\end{array}$ \\
\hline Graphite & -- & very low & \\
\hline lodine & -- & low & $\begin{array}{l}\text { possible by-product of oil- } \\
\text { field brines }\end{array}$ \\
\hline Lead & high & low & $\begin{array}{l}\text { may be part of } \\
\text { significant zinc-lead-silve } \\
\text { district }\end{array}$ \\
\hline Manganese & -- & low & \\
\hline Mercury & -- & very low & \\
\hline Micasheet & -- & very low & \\
\hline Nickel & -- & very low & \\
\hline $\begin{array}{l}\text { Platinum-group } \\
\text { elements }\end{array}$ & low & very low & $\begin{array}{l}\text { sub-economic concentrations } \\
\text { in placers near NPRA }\end{array}$ \\
\hline Quartz crystal & -- & very low & \\
\hline Rutile (Titanium) & - & very low & \\
\hline Sapphire and ruby & -- & very low & \\
\hline Silver & high & low & co-product of $z$ inc and lead \\
\hline Talc & -- & very low & \\
\hline Tantalum & -- & very low & \\
\hline Thorium & -- & very low & \\
\hline Tin & -- & very low & \\
\hline Tungsten & -- & very low & \\
\hline Vanadium & -- & low & \\
\hline Zinc & high & low & $\begin{array}{l}\text { may be part of zinc-lead- } \\
\text { silver district }\end{array}$ \\
\hline
\end{tabular}


TABLE TWO

ORE DEPOSIT TYPES ASSOCIATED WITH STRATEGIC AND CRITICAL MINERALS

CATEGORY ONE

High potential, identified occurrences in or near NPRA, possibility of recoverable quantities:

1. Sedimentary-exhalative, sediment-hosted zinc-lead-silver (lead, zinc, silver, cadmium, antimony)

2. Massive sulfide associated with felsic to intermediate volcanics (lead, zinc, silver, cadmium, antimony)

\section{CATEGORY TWO}

Some potential, identified occurrence in or near NPRA, low probability of recoverable quantities:

1. Fluorite veins in carbonates

(fluorspar)

2. Chromite in ophiolitic ultramafic rocks

(chromium)

3. Placers derived from ultramafic plutons

(platinum-group elements)

\section{CATEGORY THREE}

Some potential, no identified occurrence in or near NPRA, permissible geological conditions within NPRA, unknown quantities:

1. Carbonate-hosted lead-zinc (Mississippi Valley type)

(lead, zinc, fluorspar, cadmium, antimony, copper, cobalt, bismuth)

2. Dolomite-hosted discordant copper-cobalt (Ruby Creek type)

(copper, cobalt, zinc, lead, antimony)

3. Massive sulfide in basaltic rocks (Cyprus type)

(copper, zinc)

4. Sandstone uranium-vanadium

(vanadium) 
5. $\quad 0 i l$ and gas field byproducts (iodine, vanadium)

6. Sedimentary manganese (manganese)

7. "Fossil" placer

(beryllium, tantalum, tin, titanium (rutile), thorium, ruby and sapphire)

\section{CATEGORY FOUR}

Very low potential, not identified in or near NPRA, permissible geological conditions are unlikely within NPRA:

1. Mafic and ultramafic layered or zoned intrusions

(chromium, copper, nickel, platinum-group elements, titanium)

2. Serpentinized ultramafics

(asbestos, talc)

3. Kimberlites

(diamond)

4. Alkalic igneous rocks and carbonatites

(Fluorspar, columbium, titanium)

5. Granitic to intermediate intrusions and associated skarns and veins (copper, lead, silver, tin, tungsten, zinc)

6. Pegmatites

(beryllium, micasheet, quartz crystal, columbium, thorium, tantalum, ruby and sapphire)

7. High-grade metamorphic rocks (graphite, talc)

8. Epithermal veins

(antimony, beryllium, bismuth, cadmium, copper, fluorspar, lead, silver)

9. Hot springs

(antimony, mercury)

10. Laterites

(aluminum, cobalt, nickel) 